\title{
Biomechanical Comparison of Different Fixation Systems after Le Fort I Advancement Osteotomy: An in Vitro Study
}

\author{
Mehmet Melih Ömezli(0000-0003-3589-1889) ${ }^{\alpha}$, Ferhat Ayrancı(0000-0002-6606-6593) ${ }^{\alpha}$, Damla Torul(0000-0003-3589-1889) ${ }^{\alpha}$,
} Mustafa Ay(0000-0003-2323-606X) ${ }^{\alpha}$

Selcuk Dent J, 2021; 8: 729-735 (Doi: 10.15311/selcukdentj.783190)

Başvuru Tarihi: 21 Ağustos 2020 Yayına Kabul Tarihi: 21 Aralı 2020

\begin{abstract}
Biomechanical Comparison of Different Fixation Systems after Le Fort I Advancement Osteotomy: An in Vitro Study

Background: The aim of this study is to explore the effect of five different plate-screw systems on the stability after LeFort I osteotomy in polyurethane skull models.

Materials and Methods: Standard titanium miniplates, titanium microplates and bioabsorbable plates were applied for the internal fixation of artificially created LeFort I osteotomy on polyurethane skulls. Load applied in inferior-superior direction to simulate bite forces. The load-displacement values were recorded.

Results: Significant differences were observed among the displacement values of five fixation systems at 120, 150, 180 and $200 \mathrm{~N}$ of loading $(p<0.05)$. The highest displacement values were observed in the 4RLt-Micro group with the increasing load. The 4RLt-Mini and 4LLt-Mini groups showed the least displacement values, and the 4LLt-Mini group showed less displacement than the 4RLt-Mini group. The 2Lt/2lt- Mini and $2 \mathrm{Lt} / 2 \mathrm{Ir}$-Mini groups showed proximate displacement values with the 4RLt-Mini and 4LLt-Mini groups.
\end{abstract}

Conclusion: The results of this study show that the left sided $L$ miniplates provide more stable results than the right sided ones. Also, it may be said that while sufficient stability can be obtained, the problem of palpability is also eliminated with the use of bioabsorbable plates in the regions with thin muscularity in combination with standard titanium miniplates. However, further in vitro and in vivo studies needs to be conducted to confirm these results.

\section{KEYWORDS}

Bioabsorbable system, Microplate, Stability, Advancement, Le Fort osteotomy

The Le Fort I osteotomy is a versatile surgical approach commonly preferred to manage maxillary discrepancies in 3 planes of space..$^{1-3}$ Post-operative stability is the sine qua non of the long-term success of this procedure and depends largely on the internal fixation. ${ }^{4,5}$ Titanium plates and screws are preferred as a standard approach for internal fixation for almost 2 decades. ${ }^{4,6,7}$ However, several shortcomings such as local irritation, growth disturbance, migration, infection, dysaesthesia, thermal sensitivity, image distortion, metal deposition, palpability and damage to vital anatomic structures have been occurred
ÖZ

Le Fort I İlerletme Osteotomisi Sonrası Farklı Fiksasyon Sistemlerinin Biyomekanik Olarak Karşılaştırması: İn Vitro Çalışma

Amaç: Bu çalışmanın amacı, poliüretan kafatası modellerinde Le Fort I osteotomisi sonrası beş farklı plak-vida sisteminin stabilite üzerindeki etkisini araştırmaktır.

Gereç ve Yöntemler: Poliüretan kafataslarında deneysel olarak oluşturulan Le Fort I osteotomisinin fiksasyonu için standart titanyum mini plaklar, titanyum mikroplaklar ve rezorbe olabilen plakalar uygulandı. Isırma kuvvetlerini simüle etmek için inferiorsüperior yönde kuvvet uygulandı. Kuvvet-yer değiştirme değerleri kaydedildi.

Bulgular: 120, 150, 180 ve $200 \mathrm{~N}$ yüklemede beş farklı fiksasyon sisteminin yer değiştirme değerleri arasında önemli farklılıklar gözlendi $(p<0.05)$. En yüksek deplasman değerleri, artan yük ile 4RLt-Micro grubunda gözlendi. 4RLt-Mini ve 4LLt-Mini grupları en düşük yer değiştirme değerlerini gösterdi. 4LLt-Mini grubu 4RLtMini grubundan daha az yer değiştirme gösterdi. 2Lt / 2lt-Mini ve 2Lt / 2Ir-Mini grupları, 4RLt-Mini ve 4LLt-Mini grupları ile yaklaşık deplasman değerleri gösterdi.

Sonuç: Bu çalışmanın sonuçları, sola bakan $L$ mini plakaların sağa bakanlara göre daha stabil sonuçlar verdiğini göstermektedir. Rezorbe olabilen plakların standart titanyum mini plaklar ile kombine halde kullanımasıyla yeterli stabilite elde edilirken, aynı zamanda kas yapısı ince olan bölgelerde palpabilite probleminin de ortadan kalktığı söylenebilir. Bununla birlikte, bu sonuçları doğrulamak için daha fazla in vitro ve in vivo çalışmaların yapılması gerekmektedir.

\section{ANAHTAR KELIMELER}

Rezorbe olabilen sistem, Mikroplak, Stabilite, İlerletme, Le Fort osteotomisi

associated with the use of miniplate systems. ${ }^{6,8,9}$ It is reported that in more than $10 \%$ of patients these shortcomings necessitate the removal of the plates, and the prominence/palpability and pain are the main reasons for mini plate removal in the midface..$^{10-12}$

The disadvantages of miniplate systems increase the demand for new osteosynthesis materials that could eliminate or compensate for these shortcomings. Microdimensioned systems introduced by Hans Luhr in the late 1980s and despite the miniplate systems microplates require less manipulation, can easily adapt

${ }^{\alpha}$ Ordu University Faculty of Dentistry, Department of Oral and Maxillofacial Surgery, Ordu, Turkey. 
to the bone, are associated with lower probability of iatrogenic damage, deposition of titanium deposits and palpability in patients with thin muscularity. ${ }^{9,13,14}$ Bioabsorbable systems are also considered as a feasible alternative with their ability to withstand forces until bony healing by achieving a balance between resorption and bone replacement. ${ }^{15,16}$ Self-degradation potential of bioabsorbable systems obviate the necessity of the removal of fixation system with a second surgery, and the palpability disadvantage of miniplate systems. ${ }^{12,16}$ Bioabsorbable and microplate systems have been used successfully for the internal fixation of fractures and osteotomies of the craniomaxillofacial region..$^{9,17-23}$

To date the success of various fixation systems have been explored for maxillary stabilization after Le Fort I procedure in several studies., ${ }^{3,5,6,24-26}$ However, questions still present in terms of the fixation system that provide the optimal outcomes. The hypothesis of this study is that the use of micro and resorbable systems in the posterior maxilla where the muscularity is relatively thin, in combination with miniplate systems, would result in promising outcomes to provide enough stability and overcome the problem of palpability. The aim of this in vitro study is to explore the effect of five different plate-screw systems on the stability after Le Fort I procedure in polyurethane skull models. Also, we aimed secondarily to evaluate the efficiency of the use of micro and bioabsorbable fixation systems especially in the regions where the muscularity is relatively thin, in providing enough stability.

\section{MATERIALS AND METHODS}

Synthetic polyurethane skull models (Synbone 8220, Synbone AG, Switzerland) were used to carry out this in vitro study. Conventional Le Fort I osteotomy was performed on the skull models with reference to anatomical landmarks orbital wall, the zygomatic buttress, and the teeth. All the cuts were standardized with acrylic guide to simulate the same fracture line homogenously with a steel saw and electronic micromotor (Figure 1). After positioning the excised maxilla uniformly using reference lines $5 \mathrm{~mm}$ advancement performed and fixed to the skull by means of a wax leaving a 3-mm gap between the segments to prevent bone contact and allow measurement of plate strength. ${ }^{27}$ Stability of five different plate systems ( $n=5$ for each system) have been tested:

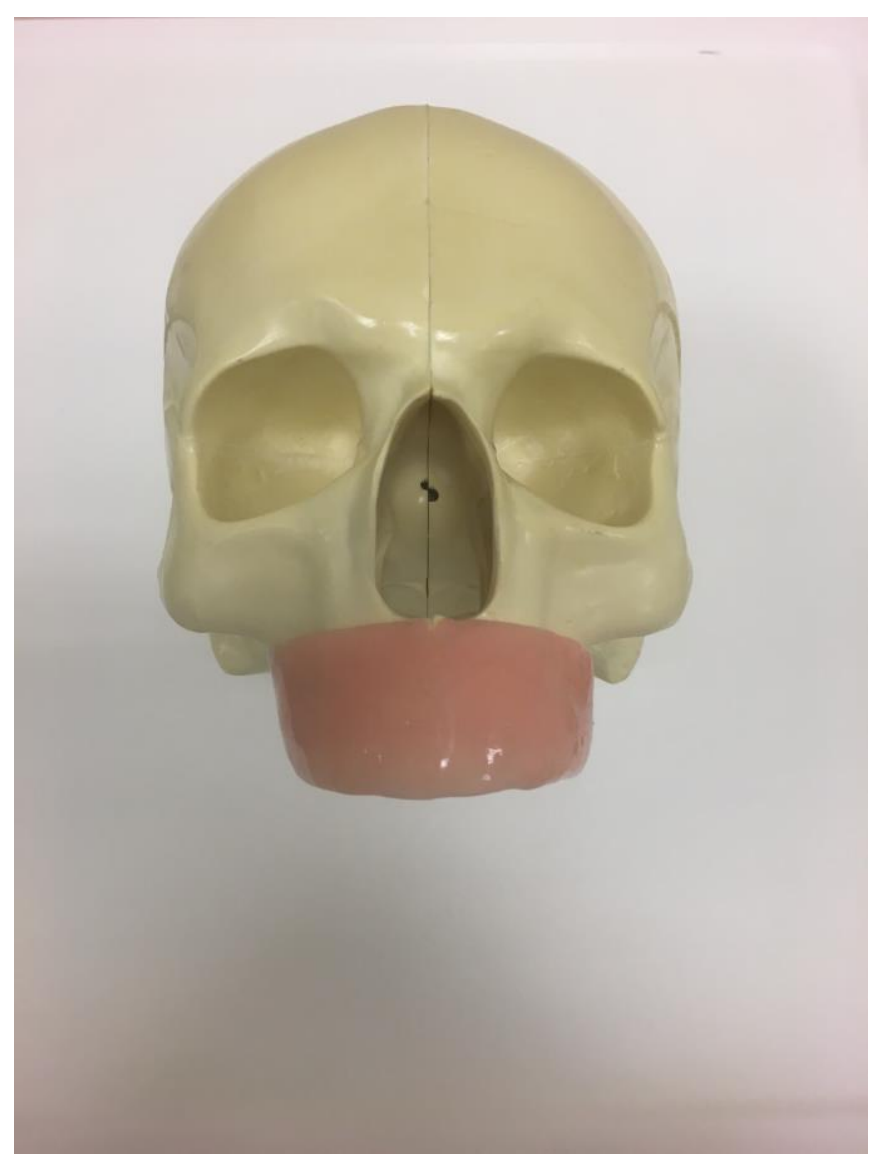

Figure 1

Acrylic guide

In the first group (4RLt-Mini), standard right sided 4hole, L-shaped titanium mini-plates and screws $(1 \mathrm{~mm}$ thick plate $/ / 2 \times 7 \mathrm{~mm}$ screw) were placed bilaterally on the zygomatic buttress and piriform rim. In the second group (4LLt-Mini), standard left sided 4-hole, L-shaped titanium mini-plates and screws $(1 \mathrm{~mm}$ thick plate//2x7mm screw) were placed bilaterally on the zygomatic buttress and piriform rim. In the third group (4RLt-Micro), standard right sided 4-hole, L-shaped titanium micro-plates and screws $(0.6 \mathrm{~mm}$ thick plate $/ 1.6 \times 7 \mathrm{~mm}$ screw) were placed bilaterally on the zygomatic buttress and piriform rim. In the fourth group (2Lt/2lt-Mini), standard right sided 4-hole, Lshaped titanium mini-plates and screws $(1 \mathrm{~mm}$ thick plate//2x7mm screw) were placed to the piriform rim while straight 4-hole miniplate and screws $(1 \mathrm{~mm}$ thick plate//2x7mm screw) were placed on the zygomatic buttresses, bilaterally. In the fifth group (2Lt/2Ir-Mini), standard right sided 4-hole, L-shaped titanium miniplates and screws ( $1 \mathrm{~mm}$ thick plate $/ / 2 \times 7 \mathrm{~mm}$ screw) were placed to the piriform rim while straight 4-hole bioabsorbable plate and screws $(2 \mathrm{~mm}$ thick plate//2x7mm screw) were placed on the zygomatic 
buttresses, bilaterally (all metallic fixation systems were Trimed Titanium Implant System, Trimed Medical, Ankara, Turkey and all bioabsorbable systems were Lactosorb, Biomet, Florida, USA), (Figure 2).

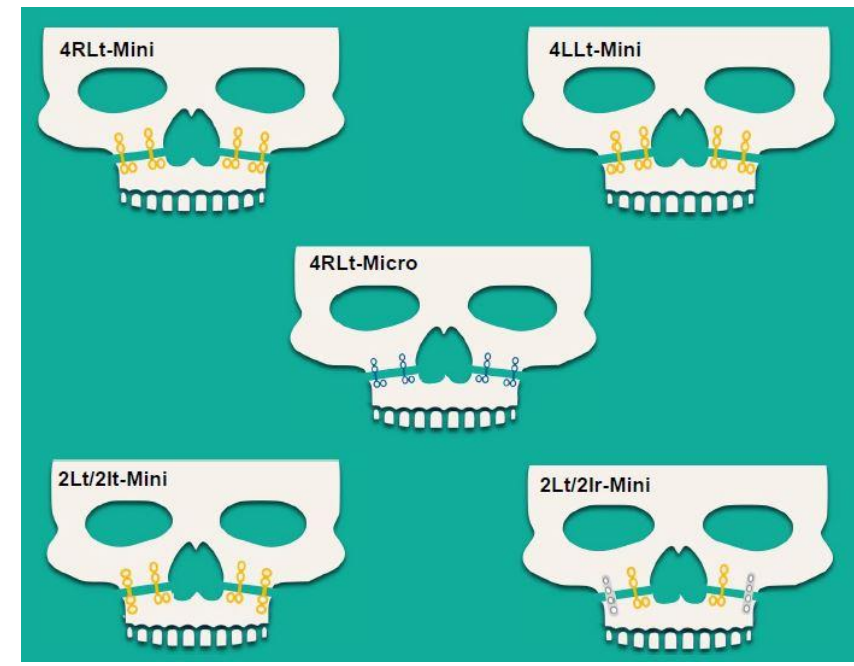

Figure 2

Study groups

A custom made fixation appliance, used to fixed the skull models to the test device (Autograph AGS X; Shimadzu Co, Japan). Each models was fixed in similar fashion to the testing machine and the maxilla was positioned parallel to the ground plane. 10 Newton of pre-loads were applied before the tests for standardization. All testing was performed on a servo hydraulic testing machine (Figure 3 ).

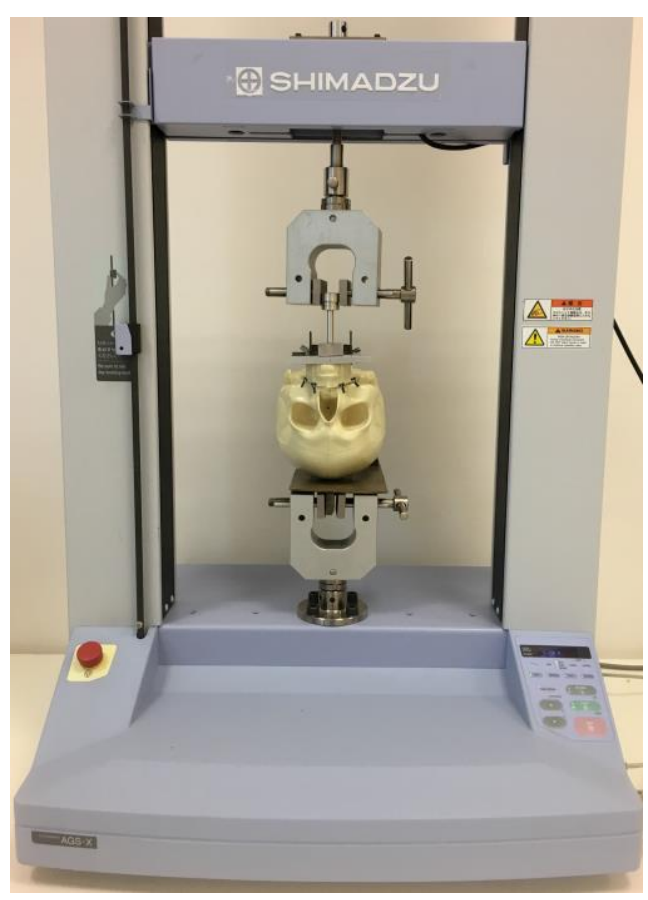

Figure 3

Created 3D mandible model and coordinate system.
The data was recorded digitally on a software (Trapezium X Shimadzu Co, Japan) that shows the load and displacement results. Loads of 120, 150, 180 and 200 Newton was applied to the skull models in the infero-superior (IS) direction to simulate the bite forces, and the data of displacement under linear loads were measured. Five repetitions of each test group were performed. Statistical analyses were performed with the IBM SPSS Statistics for Windows software (version 23.0, IBM Corp, Armonk, NY). The comparison between groups was analyzed using the Kruskal Wallis test with pairwise comparisons. $P$ value $<0.05$ considered as significant.

\section{RESULTS}

The displacement values among the groups presented as mean \pm SD and shown in Table 1. The results of this study show that there were significant differences among the displacement values of five fixation systems on 120, 150, 180 and $200 \mathrm{~N}$ of loading $(p<0.05)$, (Graph 1).

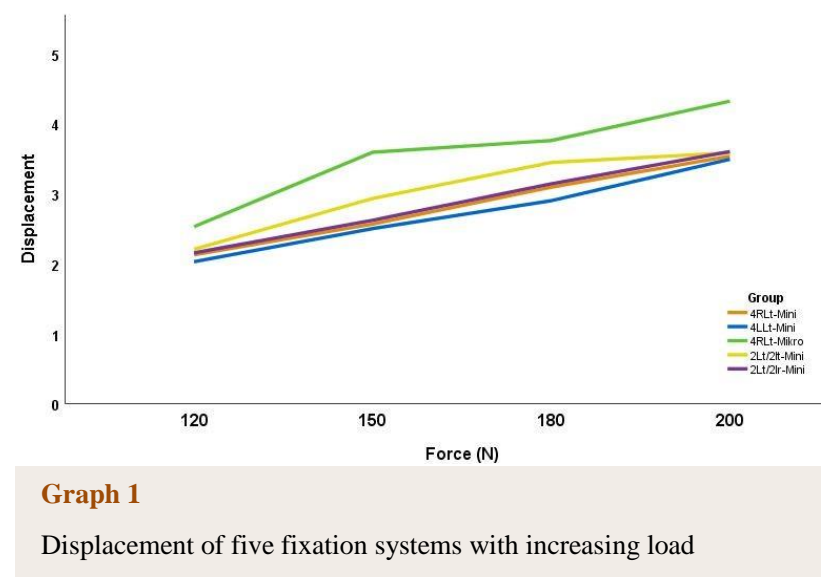

At $120 \mathrm{~N}$ loading significant differences were observed between the 4RLt-Mini group and the 4RLt-Micro $(p=0.01)$, 2Lt/2lt-Mini $(p=0.032)$ groups; the 4LLt-Mini group and the 4RLt-Micro $(p<0.01)$, 2Lt/2It-Mini $(p=0.01)$, 2Lt/2lr-Mini $(p=0.032)$ groups; the 4RLt-Micro group and the 2Lt/2Ir-Mini $(p=0.032)$ group. At $150 \mathrm{~N}$ loading significant differences were observed between the 4RLt-Mini group and the 4RLt-Micro $(p<0.01)$, 2Lt/2lt-Mini $(p=0.005)$ groups; the 4LLt-Mini group and the 4RLt-Micro $(p<0.01)$, 2Lt/2lt-Mini $(p=0.010)$ groups; the 4RLt-Micro group and the $2 \mathrm{Lt} / 2 \mathrm{Ir}-\mathrm{Mini}(\mathrm{p}=0.032)$ group. At $180 \mathrm{~N}$ loading significant differences were observed between the 4RLt-Mini group and the 4RLt-Micro $(p=0.01), 2 L t / 2$ lt-Mini $(p=0.032)$ groups; the 4LLtMini group and the 4RLt-Micro $(p<0.01)$, 2Lt/2lt-Mini $(p=0.001)$, 2Lt/2lr-Mini $(p=0.032)$ groups; the 4RLtMicro group and the 2Lt/2Ir-Mini $(p=0.032)$ group. At $200 \mathrm{~N}$ loading significant differences were observed between the 4RLt-Mini group and the 
4RLt-Micro $(p<0.01)$, 2Lt/2Ir-Mini $(p=0.007)$ groups; the 4LLt-Mini group and the 4RLt-Micro $(p=0.006)$ group; the 4RLt-Micro group and the 2Lt/2It-Mini $(p=0.007)$ group. Pairwise comparisons shown in Graph 2.

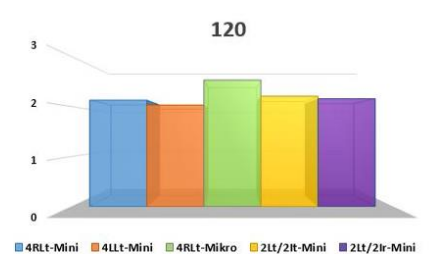

180

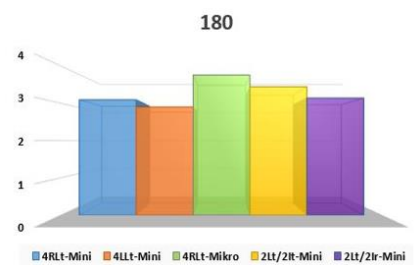

Graph 2

Comparisons of displacement among groups A: at $120 \mathrm{~N}, \mathrm{~B}$ : at $150 \mathrm{~N}, \mathrm{C}$ : at $180 \mathrm{~N}, \mathrm{D}$ at $200 \mathrm{~N}$.

\section{DISCUSSION}

Stability after Le Fort I osteotomy is still an issue of concern despite the enormous revolutions in the biomedical field. ${ }^{2,28}$ Several in vitro studies have been conducted by using fixation systems with different patterns in an attempt to determine the optimum plate configuration that could provide the most stable outcomes. Arajuo et $\mathrm{al}^{6}$ who compare the stability of titanium, prebent, bioabsorbable plates and bioabsorbable mesh after Le fort I osteotomy with $8 \mathrm{~mm}$ advancement on 3D skull models reported that the bioabsorbable systems were adequate for fixation. In a finite element analysis (FEA) study Uçkan et $\mathrm{al}^{4}$ explored the stability of titanium and bioabsorbable fixation systems after Le Fort I osteotomy and suggested that in advancement of $5 \mathrm{~mm}$ or more, bioabsorbable plates should be used with caution. Prebent and patient specific plates suggested offering a good alternative to the conventional plate system after Le Fort I osteotomy in FEA study of Coskunses et $\mathrm{al}^{3}$, and in vitro studies of Pozzer et $\mathrm{al}^{24}$ and Stockboro et al. $^{29}$ In another study Huang et $\mathrm{al}^{5}$ investigated the stability of different fixation patterns including LL, LI, and II after Le Fort I advancement osteotomy up to 9 $\mathrm{mm}$ and suggested L-shaped mini-plates for lateral fixation.

From clinical point of view, a recent systematic review conducted by Passeri et $\mathrm{al}^{30}$ suggested that bioabsorbable and metal fixation systems seem to be equivalent with respect to stability and morbidity. In most of the clinical studies in the literature it is reported that the use of different bioabsorbable materials
PLLA/PGA, 70/30 PLDLLA, (u-HA)/PLLA, or PLLA after Le Fort I osteotomy reported being an acceptable alternative to conventional titanium miniplate fixation. ${ }^{7,12,16,26,31}$ In terms of palpability and need for second surgery, bioabsorbable materials also reported as advantageous. ${ }^{12,16}$ On the contrary Gareb et $\mathrm{al}^{32}$ claimed that the performance of the biodegradable system was inferior compared to the titanium system in their clinical study with $>5$ years follow-up. In addition, some of the researchers mentioned that clinically acceptable instability may occur especially in vertical dimensions in the early postoperative period with bioabsorbable fixation, and suggested to use the bioabsorbale systems in wide surgical movements with caution. ${ }^{12,15-17,31}$

Although numerous in vitro and clinical studies conducted with different designs and results, questions still present regarding the fixation system that could provide the optimum outcomes after Le Fort I osteotomy. Also, to our knowledge no in vitro study has been conducted to explore the stability of microplate systems which have been reported to be a reliable modality used for internal fixation in cranio-maxillofacial region, after Le Fort I osteotomy. ${ }^{9,13,20,33}$ Thus we planned an in vitro study to explore an effective fixation pattern that could provide adequate stability and overcome the shortcomings of the conventional system. To achieve this goal we tested 5 different fixation patterns on 3D polyurethane skull models to simulate clinical conditions of maxillary advancement and loading.

Because of the different study designs and materials used in different studies, it is difficult to compare the biomechanical behavior of the fixation systems among studies. According to the data obtained from the results of our study, the highest displacement values were observed in the 4RLtMicro group with the increasing load. The 4RLt-Mini and the 4LLt-Mini groups showed the least displacement values, and the 4LLt-Mini group showed less displacement than the 4RLt-Mini group. This finding supports our hypothesis that the direction of the $L$ shaped miniplate is important in terms of stability, and left sided $L$ plates provide more stable results than right sided ones. This result may be originated from that the left sided $L$ plates provide better stability by having more adaptation to the posterior regions with higher masticatory loads. The 2Lt/2lt-Mini and the 2Lt/2Ir-Mini groups showed proximate displacement values with the 4RLt-Mini and the 4LLt-Mini groups. According to this result it may be said that while sufficient stability can be obtained, the problem of palpability is also eliminated with the use of bioabsorbable plates in the regions with thin muscularity in combination with standard titanium miniplates. 
Bone healing after Le Fort I osteotomy is a complex process which includes different biological mechanisms in each step of healing. In the first 4 to 6 weeks of the healing protection with adequate fixation is required because the callus is very weak in terms of resistance to movement/forces and adequate strength is typically achieved in 3 to 6 months. ${ }^{34}$ Also, the muscular forces change during the healing process. The maximum bite force showed a general decrease during the first few months after surgery, and then increase gradually. ${ }^{27,35}$ Feller et $\mathrm{al}^{20}$ reported that the masticatory loads exciding $200 \mathrm{~N}$ occur 3 months after fixation. Song et $\mathrm{a}^{36}$ also reported bite forces of $240 \mathrm{~N}$ between the molars after 6 months after Le Fort osteotomy. Studies suggest that all methods of fixation have a similar resistance to the occlusal forces in the early period. ${ }^{27,35,36}$ Esen et $\mathrm{al}^{27}$ reported that up to $80 \mathrm{~N}$ the IS displacement was not significant among groups. In early period of healing stability can be achieved easily by fixation systems because of the reduced muscular function. Thus, it is important for the applied fixation system to withstand the forces and provide adequate stability in the critical healing period. Therefore, we compare displacement at 120, 150, 180 and $200 \mathrm{~N}$ forces to evaluate the stability of the systems with the increasing bite forces during this critical healing period when the bone did not reach sufficient strength.

Some limitations regarding this study should be considered when interpreting the results. Although we used 3D skull models to simulate the clinical conditions, the polyurethane models are different from natural structure of the bone. Because of the in vitro nature of the study it is not possible to exactly reproduce real time clinical conditions as the forces that affect the maxilla are multidirectional and the healing of the bone is a dynamic process rather than static with gradually increased forces. Also, we only tested $5 \mathrm{~mm}$ advancement.

The results of this study show that the left sided $L$ plates provide more stable results than right sided ones. Also, it may be said that while sufficient stability can be obtained, the problem of palpability is also eliminated with the use of bioabsorbable plates in the regions with thin muscularity when used in combination with standard titanium miniplates. However, further in vitro and in vivo studies with wider advancement values and by considering the disadvantages of bioabsorbable and microplate systems need to be conducted to confirm these results.

\section{Acknowledgement}

This study was supported within the scope of the project numbered $\mathrm{A}-1815$, which was accepted by the Ordu University Scientific Research Projects Commission. 


\section{REFERENCES}

1. Susarla SM, Ettinger R, Preston K, Kapadia $H$, Egbert MA. Two-point nasomaxillary fixation of the Le Fort I osteotomy: assessment of stability at one year postoperative. Int $\mathrm{J}$ Oral Maxillofac Surg. 2020;49(4):466-470.

2. Erkmen E, Atac MS, Yucel E, Kurt A. Comparison of biomechanical behaviour of maxilla following Le Fort I osteotomy with 2- versus 4-plate fixation using 3D-FEA: part 3: inferior and anterior repositioning surgery. Int $\mathrm{J}$ Oral Maxillofac Surg. 2009;38(2):173-179.

3. Coskunses FM, Kan B, Mutlu I, Cilasun U, Celik T. Evaluation of prebent miniplates in fixation of Le Fort I advancement osteotomy with the finite element method. J Craniomaxillofac Surg. 2015;43(8):1505-1510.

4. Uckan S, Veziroglu F, Soydan SS, Uckan E. Comparison of stability of resorbable and titanium fixation systems by finite element analysis after maxillary advancement surgery. J Craniofac Surg. 2009;20(3):775-779.

5. Huang SF, Lo LJ, Lin CL. Biomechanical interactions of different mini-plate fixations and maxilla advancements in the Le Fort I Osteotomy: a finite element analysis. Comput Methods Biomech Biomed Engin. 2016;19(16):1704-1713.

6. Araujo MM, Waite PD, Lemons JE. Strength analysis of Le Fort I osteotomy fixation: titanium versus resorbable plates. J Oral Maxillofac Surg. 2001;59(9):1034-1039; discussion 1039-1040.

7. Kim BC, Padwa BL, Park HS, Jung YS. Stability of maxillary position after Le Fort I osteotomy using self-reinforced biodegradable poly-70L/30DLlactide miniplates and screws. J Oral Maxillofac Surg. 2011;69(5):1442-1446.

8. Gupta A, Singh V, Mohammad S. Bite force evaluation of mandibular fractures treated with microplates and miniplates. J Oral Maxillofac Surg. 2012;70(8):1903-1908.

9. Farole A, Diecidue RJ. Microscrew and microplate systems for select osteotomies in orthognathic surgery. Oral Surg Oral Med Oral Pathol. 1993;75(3):276-279.

10.Pinto CM, Asprino L, de Moraes M. Chemical and structural analyses of titanium plates retrieved from patients. Int $\mathrm{J}$ Oral Maxillofac Surg. 2015;44(8):1005-1009.

11.Schmidt BL, Perrott DH, Mahan D, Kearns G. The removal of plates and screws after Le Fort I osteotomy. J Oral Maxillofac Surg. 1998;56(2):184-188.

12. Norholt SE, Pedersen TK, Jensen J. Le Fort I miniplate osteosynthesis: a randomized, prospective study comparing resorbable PLLA/PGA with titanium. Int $\mathrm{J}$ Oral Maxillofac Surg. 2004;33(3):245-252.
13.Schortinghuis J, Bos RR, Vissink A. Complications of internal fixation of maxillofacial fractures with microplates. J Oral Maxillofac Surg. 1999;57(2):130134; discussion 135.

14.Xie ST, Singhal D, Chen CT, Chen YR. Functional and radiologic outcome of open reduction and internal fixation of condylar head and neck fractures using miniplate or microplate system. Ann Plast Surg. 2013;71 Suppl 1:S61-66.

15.Park JH, Kim M, Kim SY, Jung HD, Jung YS. Threedimensional analysis of maxillary stability after Le Fort I osteotomy using hydroxyapatite/poly-L-lactide plate. J Craniomaxillofac Surg. 2016;44(4):421-426.

16. Cheung LK, Yip IH, Chow RL. Stability and morbidity of Le Fort I osteotomy with bioresorbable fixation: a randomized controlled trial. Int J Oral Maxillofac Surg. 2008;37(3):232-241.

17. Costa F, Robiony M, Zorzan E, Zerman N, Politi M. Stability of skeletal Class III malocclusion after combined maxillary and mandibular procedures: titanium versus resorbable plates and screws for maxillary fixation. $\mathrm{J}$ Oral Maxillofac Surg. 2006;64(4):642-651.

18.Dhol WS, Reyneke JP, Tompson B, Sandor GK. Comparison of titanium and resorbable copolymer fixation after Le Fort I maxillary impaction. Am J Orthod Dentofacial Orthop. 2008;134(1):67-73.

19.Eppley BL, Prevel CD. Nonmetallic fixation in traumatic midfacial fractures. J Craniofac Surg. 1997;8(2):103-109.

20. Feller KU, Richter G, Schneider M, Eckelt U. Combination of microplate and miniplate for osteosynthesis of mandibular fractures: an experimental study. Int $\mathrm{J}$ Oral Maxillofac Surg. 2002;31(1):78-83.

21.Ferretti C, Reyneke JP. Mandibular, sagittal split osteotomies fixed with biodegradable or titanium screws: a prospective, comparative study of postoperative stability. Oral Surg Oral Med Oral Pathol Oral Radiol Endod. 2002;93(5):534-537.

22. Haers PE, Sailer HF. Biodegradable self-reinforced poly-L/DL-lactide plates and screws in bimaxillary orthognathic surgery: short term skeletal stability and material related failures. J Craniomaxillofac Surg. 1998;26(6):363-372.

23. Omezli MM, Torul D, Polat ME, Dayi E. Biomechanical comparison of osteosynthesis with poly-L-lactic acid and titanium screw in intracapsular condylar fracture fixation: An experimental study. Niger J Clin Pract. 2015;18(5):589-593.

24.Pozzer L, Olate $S$, Cavalieri-Pereira L, Navarro P, de Albergaria Barbosa JR. Mechanical stability of 2plate versus 4-plate osteosynthesis in advancement Le Fort I osteotomy. An in vitro study. J Stomatol Oral Maxillofac Surg. 2017;118(1):2-4.

25. Murray RA, Upton LG, Rottman KR. Comparison of the postsurgical stability of the Le Fort I osteotomy using 2- and 4-plate fixation. J Oral Maxillofac Surg. 2003;61(5):574-579. 
26. Ueki K, Okabe K, Moroi A, et al. Maxillary stability after Le Fort I osteotomy using three different plate systems. Int $\mathrm{J}$ Oral Maxillofac Surg. 2012;41(8):942-948.

27.Esen A, Isik K, Saglam H, Ozdemir YB, Dolanmaz D. Biomechanical evaluation of different fixation systems after Le Fort I osteotomy in polyurethane models of unilateral clefts. $\mathrm{Br} \mathrm{J}$ Oral Maxillofac Surg. 2016;54(7):757-761.

28. Atac MS, Erkmen E, Yucel E, Kurt A. Comparison of biomechanical behaviour of maxilla following Le Fort I osteotomy with 2- versus 4-plate fixation using 3D-FEA Part 2: impaction surgery. Int $\mathrm{J}$ Oral Maxillofac Surg. 2009;38(1):58-63.

29. Stokbro K, Borg SW, Andersen MO, Thygesen T. Patient-specific 3D printed plates improve stability of Le Fort 1 osteotomies in vitro. J Craniomaxillofac Surg. 2019;47(3):394-399.

30.Passeri LA, Bento AM, Vanni T. Resorbable Versus Titanium Fixation of Le Fort I Osteotomy. J Craniofac Surg. 2020.

31. Ueki K, Marukawa K, Shimada M, Nakagawa K, Alam S, Yamamoto E. Maxillary stability following Le Fort I osteotomy in combination with sagittal split ramus osteotomy and intraoral vertical ramus osteotomy: a comparative study between titanium miniplate and poly-L-lactic acid plate. J Oral Maxillofac Surg. 2006;64(1):74-80.

32. Gareb B, van Bakelen NB, Buijs GJ, et al. Comparison of the long-term clinical performance of a biodegradable and a titanium fixation system in maxillofacial surgery: A multicenter randomized controlled trial. PLoS One. 2017;12(5):e0177152.

33. Choi TJ, Chung YH, Cho JY, Burm JS. The Use of Microplates for Internal Fixation of Comminuted Mandibular Fractures. Ann Plast Surg. 2019;82(1):55-61.

34. Kalfas IH. Principles of bone healing. Neurosurg Focus. 2001;10(4):E1.

35. Choi YJ, Lim H, Chung CJ, Park KH, Kim KH. Two-year follow-up of changes in bite force and occlusal contact area after intraoral vertical ramus osteotomy with and without Le Fort I osteotomy. Int J Oral Maxillofac Surg. 2014;43(6):742-747.

36.Song HC, Throckmorton GS, Ellis E, 3rd, Sinn DP. Functional and morphologic alterations after anterior or inferior repositioning of the maxilla. $J$ Oral Maxillofac Surg. 1997;55(1):41-49; discussion 49-50
Corresponding Author:
Mustafa AY
Ordu University
Faculty of Dentistry
Department of Oral and Maxillofacial Surgery
Ordu, Turkey
E-mail : mustafaayy55@gmail.com 